\title{
Attenuation of Cardiovascular Responses to Laryngoscopy and Intubation with Lignocaine and Esmolol in Patients Undergoing Elective Surgery
}

\author{
Sreesabari S. ${ }^{1}$, Remiya R.P. ${ }^{2}$, Nithin Sathyan ${ }^{3}$, Sajil M.S. ${ }^{4}$ \\ 1,2,3,4 Department of Anaesthesiology, Travancore Medical College, Kollam, Kerala, India.
}

\section{ABSTRACT}

\section{BACKGROUND}

Direct laryngoscopy and endotracheal intubation frequently induce a cardiovascular stress response characterized by hypertension and tachycardia due to reflex sympathetic discharge due to laryngotracheal stimulation which leads to increased plasma nor epinephrine concentration. The response is transient occurring 30 seconds after intubation and lasting for less than 10 minutes. Laryngoscopy and endotracheal intubation are associated with undesirable haemodynamic response which is of little significance in healthy patients but may be detrimental in patients with systemic diseases like hypertension, ischemic heart disease, stroke, perforated eye injury, increased intracranial tension etc. There is a need to attenuate these haemodynamic changes to decrease the mortality and morbidity. This study is designed to evaluate the attenuation of the haemodynamic response to laryngoscopy and endotracheal intubation with available cost effective drugs (esmolol and lignocaine) which are routinely used.

\section{METHODS}

This was an observational study conducted in the department of anaesthesiology, Travancore Medical College, Kollam among 140 patients in the age group 18 to 65 years posted for elective surgery from October 2017 to September 2018. Patients who received lignocaine or esmolol as intravenous agent prior to the induction of anaesthesia were recommended to group 'L' and 'E' respectively. Blood pressure and heart rate was recorded prior to laryngoscopy as well as 1 minute, 3minutes, 5 minutes and 10 minutes after laryngoscopy and intubation. Collected data was tabulated and analyzed using appropriate statistical software (SPSS20).

\section{RESULTS}

The rise in heart rate, systolic BP, diastolic BP, and mean arterial pressure were better controlled by esmolol than lignocaine.

\section{CONCLUSIONS}

Intravenous esmolol $1.5 \mathrm{mg} / \mathrm{kg}$ is found to be more effective in the attenuation of hemodynamic responses to laryngoscopy and endotracheal intubation than intravenous lignocaine $1.5 \mathrm{mg} / \mathrm{kg}$.

\section{KEY WORDS}

Laryngoscopy, Intubation, Attenuation, Cardiovascular Response, Lignocaine, Esmolol
Corresponding Author: Dr. Nithin Sathyan, Travancore Medical College, Kollam, Kerala, India. E-mail: drnithinsathyan@gmail.com

DOI: $10.14260 / \mathrm{jemds} / 2022 / 47$

How to Cite This Article: Sreesabari S, Remiya RP, Sathyan N, et al. Attenuation of cardiovascular responses to laryngoscopy and intubation with lignocaine and esmolol in patients undergoing elective surgery. J Evolution Med Dent Sci 2022;11(01):246-252, DOI: $10.14260 / \mathrm{jemds} / 2022 / 47$

Submission 24-12-2021,

Peer Review 31-12-2021,

Acceptance 29-01-2022,

Published 31-01-2022.

Copyright (C) 2022 Sreesabari S. et al. This is an open access article distributed under Creative Commons Attribution License [Attribution 4.0 International (CC BY 4.0)] 


\section{BACKGROUND}

The circulatory response to laryngoscopy and intubation was described first by King in 1951.1,2 The extent of hemodynamic response to direct laryngoscopy by Macintosh laryngoscope and endotracheal intubation depends upon factors like distortion of airway or type and duration of physical stimulus to oropharyngeal structures. ${ }^{3}$ The principle mechanism for hypertension and tachycardia is the sympathetic response which may be due to the increase in catecholamine activity. Direct laryngoscopy and endotracheal intubation frequently induces a cardiovascular stress response characterized by hypertension and tachycardia due to reflex sympathetic simulation.

The response is transient occurring 30 sec after intubation and lasting for less than $10 \mathrm{~min} .{ }^{4}$ It may be well tolerated in healthy people, but may be hazardous in patients with hypertension, tachycardia, myocardial infarction, and other complications. Various pharmacological approaches have been used to attenuate the pressure responses to laryngoscopy and tracheal intubation. ${ }^{\text {It }}$ may predispose these patients for development of pulmonary edema, myocardial insufficiency, cerebrovascular accidents, acute left ventricular failure (LVF) and dysrhythmias. Pressor response is exaggerated in hypertensive patients even though rendered normotensive pre-operatively by antihypertensive medications. ${ }^{3,5}$

There is a need to attenuate these hemodynamic changes to decrease the mortality and morbidity. This study is designed to evaluate the attenuation of the hemodynamic response to laryngoscopy and endotracheal intubation with available cost-effective drugs which are esmolol and lignocaine.

Esmolol is a striking option among the various betablockers, because of its cardio-selectivity and ultra-short duration of action (9 minutes), but it can only be administered intravenously. Lignocaine is commonly used agent for attenuating the circulatory responses associated with tracheal intubation. ${ }^{3}$ Studies have been conducted with various drugs like lignocaine, volatile anesthetics, calcium channel blockers, beta-blockers, clonidine and vasodilators, but none of them proved to be ideal to attenuate the responses. ${ }^{5}$

The hemodynamic response to the stress of laryngoscopy and endotracheal intubation does not present a problem for most patients. However, patients with cardiovascular or cerebral disease may be at increased risk of morbidity and mortality from the tachycardia and hypertension resulting from this stress. ${ }^{6}$ In patients ranked ASA PS 1, laryngoscopy and intubation lead to an average increase in blood pressure of $40 \%$ to $50 \%$, and a $20 \%$ increase in heart rate. These changes, which are greatest one minute after intubation, last for 5 to $10 \mathrm{~min}$. They are due to sympathetic and adrenal stimulation, which may also result in some arrhythmias. About half the patient with coronary artery disease experience episodes of myocardial ischemia during intubation when no specific prevention is undertaken. ${ }^{7}$ Perioperative myocardial infarction is a leading cause of postoperative morbidity and mortality due to hypertension and tachycardia. ${ }^{8}$

Abou-Madiet $\mathrm{al}^{9}$ found that the optimal dose of lignocaine to attenuate the response as $1.5 \mathrm{mg} / \mathrm{kg}$ given 3 minutes before laryngoscopy. Miller et $\mathrm{al}^{10}$ found no benefit of intravenous lignocaine $(1.5 \mathrm{mg} / \mathrm{kg})$ given at 1,2 , or 3 minutes prior to laryngoscopy.

This study was aimed to compare the effects of lignocaine and esmolol to attenuate the cardiovascular stress response during laryngoscopy and intubation. And To assess the hemodynamic variations to laryngoscopy and intubation.

\section{METHODS}

After receiving approval from the Ethics Committee of the institution, the study was undertaken. This was an observational study conducted in the department of anaesthesiology, Travancore Medical College, Kollam among 140 patients in the age group 18 to 65 years posted for elective surgery from October 2017 to September 2018.

\section{Inclusion Criteria}

The study included patients belonging to:

- ASA-PS I or II

- Age between 18 and 65 years

- Mallampatti class I and II

- Only elective non-cardiac surgeries performed under general anesthesia.

\section{Exclusion Criteria}

Patients who were:

- At extremes of age

- Undergoing emergency surgery

- History of drug allergy

- Morbidly obese

- With difficult airway

- With cardiovascular diseases

- Heart rate less than $60 /$ minute

- $\quad$ Systolic blood pressure less than $100 \mathrm{mHg}$

- Total duration of laryngoscopy and intubation more than 15 seconds were excluded from the study.

\section{Preanesthetic Preparation}

All patients underwent a pre-anesthetic evaluation with proper history-taking and physical examination of all the systems and airway. Pre-operative routine investigations such as hemoglobin, platelet count, hematocrit, total and differential count, serum electrolytes, RFT, RBS, blood grouping and $\mathrm{Rh}$ typing, chest radiography and electrocardiogram were done. Patients were advised to fast for 6 hours before surgery. Tablet Alprazolam $0.25 \mathrm{mg}$ was given the night before surgery to allay anxiety.

\section{Anesthetic Technique}

Patient identification was done following which a short preoperative history was taken. Then, clinical examinations and routine investigations were rechecked in all patients. Study objective and procedure were explained and informed written consent taken from each patient. 
Intravenous access was secured and Ringer's lactate solution infusion started. The patients were pre-medicated with $0.004 \mathrm{mg} / \mathrm{kg}$ glycopyrrolate bromide intravenously 30 minutes prior to surgery. Then, the patient was shifted to the operating room after which routine non-invasive monitor was applied and vital signs monitored. Patients were preoxygenated for 3 minutes with $100 \%$ oxygen and then induced with $2 \mathrm{mg} / \mathrm{kg}$ propofol intravenously in incremental doses, $0.1 \mathrm{mg} / \mathrm{kg}$ vecuronium, followed by administration of the study drug (lignocaine or esmolol). Patient was ventilated with oxygen using IPPV with a fresh gas flow of $6 \mathrm{l} /$ minute until intubation. After 3 minutes of administering the study drug, laryngoscopy was done using Macintosh laryngoscope blade and trachea was intubated with an appropriate size cuffed endotracheal tube. After confirmation of the endotracheal tube placement, anesthesia was maintained with oxygen:air (50:50) and sevoflurane $2 \%$.

Heart rate, systolic blood pressure, diastolic blood pressure, mean arterial pressure changes were recorded before induction(baseline), after induction and after tracheal intubation at 1, 3, 5 and 10 minutes for the study. No painting nor draping the patient was allowed till 10 minutes after the study drug administration. Fentanyl $2 \mathrm{mcg} / \mathrm{kg}$ intravenous was given before surgery.

\section{Statistical Analysis}

Statistical analysis was done by using chi-square test and students $t$ test and the Statistical Package for the Social Sciences (SPSS 20) software was used for the data analysis. $\mathrm{P}<0.05$ was considered as the level of significance.

\section{RESULTS}

In the present study, all the patients were between the age of 18 to 65 years. The mean age for group $\mathrm{L}$ was around $38.471+/-8.8017$ years and for group E around 40.771+/8.0076 years of age in which there was no statistically significant difference in terms of age. It was observed that both groups were comparable ( $\mathrm{p}=0.108$, non significant) with respect to mean age of patient. It was observed that out of the total patient in group L, $41 \%$ were males and $29 \%$ were female, in group E, 38\% were males and 32\% were females.Statistically, both the groups were similar with respect to the gender ( $\mathrm{p}=0.367$, non significant).

In the present study it was observed that out of the total patients, in group L, $46(65 \%)$ were ASA grade 1 and $24(34.2 \%)$ were ASA grade 2, and in group E,42(60\%) were ASA grade 1 and 28 (40\%) were ASA grade 2. Statistically there was no significant difference $(\mathrm{p}=0.30)$ in the two groups in terms of ASA grading. Series 1 - ASA 1, Series 2 - ASA 2

In the present study it was observed that out of the total patients, in group L, 49(70\%) were Mallampatti class 1 and 21(30\%) were Mallampatti class 2, and in group E,40(57.1\%) were Mallampatti class 1 and 30(42.8\%) were Mallampatti class2. Statistically there was no significant difference $(p=0.08)$ in the two groups in terms of Mallampatti classification.Series 1 - Mallampatti class I, Series 2 Mallampatti class II

\section{Hemodynamic Variables}

Hemodynamic parameters were recorded at: Baseline value (Baseline readings taken before intravenous esmolol $1.5 \mathrm{mg} / \mathrm{kg}$ and lignocaine $1.5 \mathrm{~g} / \mathrm{kg}$ was given).At induction, then 1 minute, 3 minutes, 5 minutes and 10 minutes after laryngoscopy and intubation.

\begin{tabular}{|c|c|c|c|c|c|}
\hline Heart Rate & Group & $\mathbf{N}$ & Mean & $\begin{array}{c}\text { Std. } \\
\text { Deviation }\end{array}$ & $\begin{array}{c}\text { P value } \\
\text { (Students t test) }\end{array}$ \\
\hline \multirow{2}{*}{ Baseline } & Lignocaine & 70 & 79.200 & 4.3091 & \multirow{2}{*}{0.057} \\
\hline & Esmolol & 70 & 80.543 & 3.9515 & \\
\hline \multirow{2}{*}{ At induction } & Lignocaine & 70 & 73.471 & 4.7081 & \multirow{2}{*}{0.0001} \\
\hline & Esmolol & 70 & 77.786 & 5.0930 & \\
\hline \multirow{2}{*}{$\begin{array}{l}1 \text { min after } \\
\text { intubation }\end{array}$} & Lignocaine & 70 & 91.329 & 4.1867 & \multirow{2}{*}{0.0001} \\
\hline & Esmolol & 70 & 84.800 & 3.6578 & \\
\hline \multirow{2}{*}{$\begin{array}{l}3 \text { min after } \\
\text { intubation }\end{array}$} & Lignocaine & 70 & 87.543 & 4.1448 & \multirow{2}{*}{0.0001} \\
\hline & Esmolol & 70 & 81.814 & 3.0564 & \\
\hline \multirow{2}{*}{$\begin{array}{l}5 \text { min after } \\
\text { intubation }\end{array}$} & Lignocaine & 70 & 84.529 & 4.2723 & \multirow{2}{*}{0.0001} \\
\hline & Esmolol & 70 & 79.243 & 3.1689 & \\
\hline \multirow{2}{*}{$\begin{array}{l}10 \text { min after } \\
\text { intubation }\end{array}$} & Lignocaine & 70 & 82.086 & 3.8476 & \multirow{2}{*}{0.0001} \\
\hline & Esmolol & 70 & 76.843 & 3.8735 & \\
\hline
\end{tabular}

Table 1: Displays the changes in the mean heart rate at different intervals:- Mean heart rate at baseline in lignocaine group was $79.200+/-4.3091$ beats per minute(bpm) and in esmolol group was $80.543+/-3.9515$ beats per minute ( $p$ value $>0.05$, non-significant).At induction, comparison of heart rate in lignocaine group was $73.471+/-4.7081$ and in esmolol group was $77.786+/-5.0930$ ( $p$ value $>0.05$, nonsignificant).

After laryngoscopy and intubation, at $1{ }^{\text {st }}, 3^{\text {rd }}, 5$ th and 10 th minutes, comparison of heart rate in lignocaine group was $91.329+/-4.1867,87.543+/-4.1448,84.529+/-4.2723$, $82.086+/-3.8476$ respectively and in esmolol group at $1 \mathrm{st}, 3 \mathrm{rd}, 5^{\text {th }}$ and 10 th minutes were $84.800+/-3.6578,81.814$ +/- $3.0564,79.243+/-3.1689,76.843+/-3.8735$ respectively ( $\mathrm{p}$ value $<0.05$ ) which was statistically significant.

Mean heart rate at baseline in lignocaine group was $79.200+/-4.3091$ beats per minute and in esmolol group was $80.543+/-3.9515$ beats per minute $(\mathrm{p}$ value $>0.05$ nonsignificant).

At induction, the comparison of heart rate in lignocaine group was $73.471+/-4.7081$ beats per minute and in esmolol group was $77.786+/-5.0930$ beats per minute (p value $>0.05$, non- significant).

After laryngoscopy and intubation at $1 \mathrm{st}, 3 \mathrm{rd}, 5$ th and 10 th minutes, comparison of heart rate in lignocaine group was $91.329+/-4.1867,87.543+/-4.1448,84.529+/-4.2723$ and $82.086+/-3.8476$ respectively and in esmolol group at $1 \mathrm{st}, 3 \mathrm{rd}, 5^{\text {th }}$ and 10 th minutes were $84.800+/-3.6578,81.814$ +/- 3.0564, $79.243+/-3.1689$ and $76.843+/-3.8735$ respectively ( $p$ value $<0.05$ ) which were statistically significant. None of the patient in any of the study group developed bradycardia by the end of 10 th minutes of intubation and pulse rate was not less than 60 beats per minute in any of the readings.

Thus, attenuation of pressor response (rise in mean heartrate) is better in esmolol group than in lignocaine group. The mean heart rate comes near to baseline in Esmolol group at 5minutes, while it is higher in lignocaine group at all intervals. Esmolol at dose of $1.5 \mathrm{mg} / \mathrm{kg}$ provided a reliable and consistent attenuation against the increase in heart rate. 


\begin{tabular}{|c|c|c|c|c|c|}
\hline Systolic BP & Group & $\mathbf{N}$ & Mean & $\begin{array}{c}\text { Std. } \\
\text { Deviation }\end{array}$ & $\begin{array}{c}\text { P value } \\
\text { (Students ttest) }\end{array}$ \\
\hline \multirow{2}{*}{ Baseline } & Lignocaine & 70 & 123.071 & 9.3224 & \multirow{2}{*}{0.457} \\
\hline & Esmolol & 70 & 124.200 & 8.5527 & \\
\hline \multirow{2}{*}{ induction } & Lignocaine & 70 & 114.186 & 11.4212 & \multirow[b]{2}{*}{0.006} \\
\hline & Esmolol & 70 & 119.014 & 8.7865 & \\
\hline \multirow{2}{*}{$\begin{array}{l}1 \text { min after } \\
\text { intubation }\end{array}$} & Lignocaine & 70 & 143.243 & 7.1311 & \multirow{2}{*}{0.0001} \\
\hline & Esmolol & 70 & 129.514 & 7.6533 & \\
\hline \multirow{2}{*}{$\begin{array}{l}3 \text { min after } \\
\text { intubation }\end{array}$} & Lignocaine & 70 & 139.943 & 6.6461 & \multirow[b]{2}{*}{0.0001} \\
\hline & Esmolol & 70 & 125.971 & 7.4794 & \\
\hline \multirow{2}{*}{$\begin{array}{l}5 \text { min after } \\
\text { intubation }\end{array}$} & Lignocaine & 70 & 136.186 & 6.5282 & \multirow{2}{*}{0.0001} \\
\hline & Esmolol & 70 & 121.971 & 7.4093 & \\
\hline \multirow{2}{*}{$\begin{array}{l}10 \text { min after } \\
\text { intubation }\end{array}$} & Lignocaine & 70 & 130.514 & 6.2780 & \multirow{2}{*}{0.0001} \\
\hline & Esmolol & 70 & 117.143 & 7.5801 & \\
\hline & $r$ & & & & \\
\hline
\end{tabular}

Table 2:- Displays the changes in mean SBP at different time intervals in the two groups.It was seen that the baseline mean SBP in Lignocaine group was $123.071+/-9.3224 \mathrm{mmHg}$ and Esmolol group was $124.200+/-8.5527 \mathrm{mmHg}$ (p value $>0.05$ nonsignificant). At induction, values for mean SBP in Lignocaine and Esmolol group were 114.186 +/$11.4212 \mathrm{mmHg}$ and $119.014+/-8.7865 \mathrm{mmHg}$ respectively. After intubation at 1st,3rd,5th and 10th minute comparison of mean SBP in Lignocaine group were $143.243+/-7.1311$, $139.943+/-6.6461,136.186+/-6.5282$ and $130.514+/$ $6.2780 \mathrm{mmHg}$ respectively and in Esmolol group were $129.514+/-7.6533,125.971+/-7.4794$ ( $p$ value $<0.05$, significant). Maximum attenuation in mean SBP is achieved by Esmolol group $(1.5 \mathrm{mg} / \mathrm{kg}$ IV bolus) as compared to Lignocaine group $(1.5 \mathrm{mcg} / \mathrm{kg}$ IV bolus $)$ was at first minute only. Esmolol gives consistent and reliable fall in mean SBP than Lignocaine groups at all intervals.

\begin{tabular}{|c|c|c|c|c|c|}
\hline Diastolic BP & Group & $\mathbf{N}$ & Mean & $\begin{array}{c}\text { Std. } \\
\text { Deviation }\end{array}$ & $\begin{array}{c}\text { P value } \\
\text { [Students t test) }\end{array}$ \\
\hline \multirow{2}{*}{ Baseline } & Lignocaine & 70 & 77.61 & 6.789 & \multirow{2}{*}{0.084} \\
\hline & Esmolol & 70 & 79.39 & 5.123 & \\
\hline \multirow{2}{*}{ At induction } & Lignocaine & 70 & 73.40 & 6.931 & \multirow{2}{*}{0.052} \\
\hline & Esmolol & 70 & 75.41 & 5.069 & \\
\hline \multirow{2}{*}{$\begin{array}{l}1 \text { min after } \\
\text { intubation }\end{array}$} & Lignocaine & 70 & 90.23 & 6.179 & \multirow{2}{*}{0.0001} \\
\hline & Esmolol & 70 & 83.26 & 4.306 & \\
\hline \multirow{2}{*}{$\begin{array}{l}3 \text { min after } \\
\text { intubation }\end{array}$} & Lignocaine & 70 & 88.16 & 6.142 & \multirow{2}{*}{0.0001} \\
\hline & Esmolol & 70 & 80.81 & 4.084 & \\
\hline \multirow{2}{*}{$\begin{array}{l}5 \text { min after } \\
\text { intubation }\end{array}$} & Lignocaine & 70 & 85.46 & 5.750 & \multirow{2}{*}{0.0001} \\
\hline & Esmolol & 70 & 77.19 & 4.278 & \\
\hline \multirow{2}{*}{$\begin{array}{l}10 \mathrm{~min} \text { after } \\
\text { intubation }\end{array}$} & Lignocaine & 70 & 81.143 & 5.9595 & \multirow{2}{*}{0.0001} \\
\hline & Esmolol & 70 & 73.100 & 4.0366 & \\
\hline \multicolumn{6}{|c|}{$\begin{array}{c}\text { Table 3. Comparison of changes in Mean DBP ( } \mathrm{mmHg}) \text { at different } \\
\text { time interval in two groups }\end{array}$} \\
\hline
\end{tabular}

Table 3: displays the changes in mean DBP at different time interval compared to the baseline in the two groups.It was seen that the baseline mean DBP in Lignocaine group was 77.61 +/- 6.789mmHg and Esmolol group was 79.39 +/$5.123 \mathrm{mmHg}$ ( $\mathrm{p}$ value $>0.05$ non-significant). At induction, mean DBP in Lignocaine and Esmolol group were73.40 +/$6.931 \mathrm{mmHg}$ and $75.41+/-5.069 \mathrm{mmHg}$ respectively ( $p$ value $>0.05$ non-significant). After intubation at 1 st minute, $3 \mathrm{rd}$ minute, 5th and 10th minute, the mean DBP in Lignocaine group were $90.23+/-6.179 \mathrm{mmHg}, 88.16+/-6.142 \mathrm{mmHg}$, $85.46+/-5.750 \mathrm{mmHg}$ and $81.143+/-5.9595 \mathrm{mmHg}$ respectively and In Esmolol group, the mean DBP were 83.26 +/- $4.306 \mathrm{mmHg}, \quad 80.81+/-4.084 \mathrm{mmHg}, \quad 77.19$ +/$4.278 \mathrm{mmHg}$ and $73.100+/-4.0366 \mathrm{mmHg}$ respectively( $\mathrm{p}$ value $<0.05$ ) which was statistically significant.

Esmolol has a better control of the diastolic BP from the first minute after intubation and also, there is a better control of the diastolic blood pressure at different intervals as compared to lignocaine ( $p$ value $<0.05$ ).

\begin{tabular}{|c|c|c|c|c|c|}
\hline MAP & Group & $\mathbf{N}$ & Mean & $\begin{array}{c}\text { Std. } \\
\text { Deviation }\end{array}$ & $\begin{array}{c}\text { P value } \\
\text { (Students ttest) }\end{array}$ \\
\hline \multirow{2}{*}{ Baseline } & Lignocaine & 70 & 92.69 & 5.747 & \multirow{2}{*}{0.051} \\
\hline & Esmolol & 70 & 94.39 & 4.358 & \\
\hline \multirow{2}{*}{ At induction } & Lignocaine & 70 & 86.83 & 6.195 & \multirow{2}{*}{0.001} \\
\hline & Esmolol & 70 & 89.90 & 4.354 & \\
\hline \multirow{2}{*}{$\begin{array}{l}1 \text { min after } \\
\text { intubation }\end{array}$} & Lignocaine & 70 & 107.74 & 4.409 & \multirow{2}{*}{0.0001} \\
\hline & Esmolol & 70 & 98.66 & 3.926 & \\
\hline \multirow{2}{*}{$\begin{array}{l}3 \text { min after } \\
\text { intubation }\end{array}$} & Lignocaine & 70 & 105.33 & 4.252 & \multirow{2}{*}{0.0001} \\
\hline & Esmolol & 70 & 95.89 & 3.775 & \\
\hline \multirow{2}{*}{$\begin{array}{l}5 \text { min after } \\
\text { intubation }\end{array}$} & Lignocaine & 70 & 102.24 & 4.080 & \multirow{2}{*}{0.0001} \\
\hline & Esmolol & 70 & 92.03 & 3.938 & \\
\hline \multirow{2}{*}{$\begin{array}{c}10 \text { min after } \\
\text { intubation }\end{array}$} & Lignocaine & 70 & 97.50 & 4.207 & \multirow{2}{*}{0.0001} \\
\hline & Esmolol & 70 & 87.81 & 3.785 & \\
\hline & $\begin{array}{r}\text { arison of } \\
\text { tim }\end{array}$ & & $\begin{array}{l}\text { in Mear } \\
\text { in two }\end{array}$ & $\begin{array}{l}\text { oups } \\
\text { oup }\end{array}$ & er \\
\hline
\end{tabular}

Table 4: displays the changes in MAP at different time interval compared to the baseline in the two groups. It was seen that the baseline mean MAP in Lignocaine group was $92.69+/-5.747 \mathrm{mmHg}$ and in Esmolol group was $94.39+/$ $4.358 \mathrm{mmHg}$ ( $\mathrm{p}$ value $>0.05$ non-significant).At induction, MAP in Lignocaine group was $86.83+/-6.195 \mathrm{mmHg}$ and in Esmolol group was $89.90+/-4.354 \mathrm{mmHg}$ respectively. After intubation at $1 \mathrm{st}, 3^{\text {rd }}, 5$ th and 10 th minutes comparison of MAP in Lignocaine group was $107.74+/-4.409 \mathrm{mmHg}, 105.33$ +/- $4.252 \mathrm{mmHg}, 102.24+/-4.080 \mathrm{mmHg}$ and 97.50 +/$4.207 \mathrm{mmHg}$ respectively. After intubation at $1 \mathrm{st}, 3^{\mathrm{rd}}, 5^{\text {th }}$ and $10^{\text {th }}$ minutes comparison of MAP in Esmolol group was 98.66 +/-3.926 $\mathrm{mm} \mathrm{Hg}, 95.89+/-3.775 \mathrm{mmHg}, 92.03$ +/$3.938 \mathrm{mmHg}$ and $87.81+/-3.785 \mathrm{mmHg}$ respectively ( $\mathrm{p}$ value $<0.05$, significant).

Esmolol shows a better attenuation of the mean arterial pressure than lignocaine at different intervals $(\mathrm{p}<0.05$, significant).On observation, it is seen that esmolol produces a better attenuation of the hemodynamic variables than lignocaine. There is a better control of the HR and the BP by esmolol following laryngoscopy and intubation, which is done after 3 minutes of administration of esmolol. It shows that we get a better control of the stress response with $1.5 \mathrm{mg} / \mathrm{kg}$ of esmolol given 3 minutes prior to laryngoscopy and intubation than $1.5 \mathrm{mg} / \mathrm{kg}$ of lignocaine given 3 minutes before laryngoscopy and intubation.

\section{DISCUSSION}

Orotracheal intubation consists of two phases: Direct laryngoscopy and passing of endotracheal tube through the vocal cords and trachea. It has been seen in various studies that increase in HR occurs during endotracheal intubation whereas the greatest increase in BP occurs during laryngoscopy. Both sympathetic and parasympathetic element has been found as a mechanism to this intubation response. The sympathetic response is a polysynaptic pathway due to glossopharyngeal and vagus nerve forming the afferent arc to the sympathetic nervous system through the brain stem and spinal cord causing increased firing of the cardio-accelerator fibers and release of adrenergic mediators including norepinephrine, epinephrine, and vasopressin. The net effect of this autonomic surge is an increased BP, HR, pulmonary artery wedge pressure, and decreased ejection fraction. On the other hand, the parasympathetic reflex is monosynaptic, more common in children but can occur in some adults. The reflex is mediated by the increased vagal tone at the SA node. 6,11 
In 1981, Russell et al monitored the changes in arterial pressure and arterial concentrations of noradrenaline, adrenaline and dopamine were monitored in 16 patients undergoing endotracheal intubation. Significant increases in mean arterial pressure and plasma noradrenaline were noted. The increases in arterial pressure were associated with increases in noradrenaline concentrations. Adrenaline and dopamine concentrations did not change significantly following intubation. The results suggest a predominantly sympathetic response during intubation and the need for prophylaxis in patients at risk ${ }^{12}$ In 1983, Derbyshire et al measured the plasma adrenaline and noradrenaline concentrations in 24 patients during the induction of anaesthesia and the subsequent tracheal intubation. The patients received either suxamethonium $1 \mathrm{mg} \mathrm{kg}-1$ or pancuronium $0.1 \mathrm{mg} \mathrm{kg}-1$ to facilitate tracheal intubation. Mean arterial pressure (MAP) increased in both groups following laryngoscopy and tracheal intubation and there were concomitant increases in the plasma catecholamine concentrations, the changes being more marked in the suxamethonium group. There was a significant correlation between MAP and plasma catecholamine concentrations in the suxamethonium group. Measurement of plasma catecholamine concentrations in samples obtained simultaneously from central venous, peripheral venous and arterial sites were in broad agreement; the greatest changes occurred in central venous samples. ${ }^{13}$

Both HR and BP are determinants of oxygen delivery and demand. An increase in HR deleteriously affects both supply and demand of oxygen. BP is related to cardiac output (CO) and systemic vascular resistance (SVR). A change in either CO or SVR will result in a compensatory change in the other. Hypertension can, therefore, also affect both supply and demand. ${ }^{14}$ The strict control of hemodynamic variables has reduced myocardial ischemia, while hemodynamic aberrations, such as tachycardia, systolic hypertension and hypotension, elevated RPP and MBP/HR ratio of less than one may cause ischemia, RPP is correlated with myocardial oxygen demand and a threshold value of RPP had been correlated with the onset of angina. During anaesthesia, myocardial ischemia is poorly correlated with RPP.

With the development and usage of ICP monitoring devices such as the subarachnoid pressure screw and the intraventricular catheter, the intracranial effects of laryngoscopy and intubation have been studied. Burney and Winn first demonstrated that laryngoscopy and intubation could cause an increase in ICP in patients undergoing a craniotomy. ${ }^{15}$ These patients had a subarachnoid pressure screw placed for ICP monitoring. They found a rise in ICP in every patient and that the peak rise in ICP occurred within 1 minute for all but one patient (93\%). The increase in ICP from pre-induction measurements ranged from 8 to $40 \mathrm{~cm} \mathrm{H} 20$.

Suctioning, similar to laryngoscopy and intubation, seems to induce a comparable hemodynamic response. Endotracheal suctioning has also been shown to stimulate the cough reflex. ${ }^{16}$ It is hypothesized that coughing can cause an increase in intrathoracic pressure that is transmitted into the cerebral venous system and ultimately can lead to a rise in cerebral venous pressure, intracranial volume, and ICP.17 Hamill et al. compared intravenous with laryngotracheal lidocaine in 22 patients undergoing elective craniotomy. Using a subarachnoid pressure screw to measure ICP, they found that $1.5 \mathrm{mg} / \mathrm{kg}$ of intravenous lidocaine attenuated the increases in ICP, while laryngotracheallidocaine did not. ${ }^{18}$

Esmolol appears to be an appropriate choice of agent for attenuating the hemodynamic response to laryngoscopy and tracheal intubation, due to its cardioselective property, rapid onset of action and short elimination half-life $(9 \mathrm{~min})$ alongwith no significant drug interaction with commonly used anesthetics. Esmolol decreases the force of contraction and HR by blocking beta-adrenergic receptors of the sympathetic nervous system which are found in the heart, blood vessels, and other organs of the body. Esmolol prevents the action of two naturally occurring neurotransmitters epinephrine and norepinephrine, thereby attenuates the tachycardia and hypertensive responses to laryngoscopy and tracheal intubation. ${ }^{19}$ Esmolol (betaadrenergic receptor antagonist + ultra-short-acting) provides hemodynamic stability during laryngoscopy and tracheal intubation without side effects. ${ }^{20}$ Kindler et al. found that esmolol administration before laryngoscopy was sufficient to control HR after intubation, but it did not affect SAP.

Ebert et. al., found, in 68 patients undergoing general anesthesia for elective surgery, that esmolol (loading dose of $500 \mathrm{mg} / \mathrm{kg} / \mathrm{min}$ for 4 minutes, followed by a maintenance infusion of $300 \mathrm{mg} / \mathrm{kg} / \mathrm{min}$ for 11 minutes) significantly attenuated the maximum increases in HR and BP when compared with placebo. ${ }^{21}$ Korpinen et al in 1998,22 on the basis of the study concluded that propofol-alfentanil anesthesia combined with esmolol is a satisfactory method to meet specific demands of laryngomicroscopy in young and middle-aged ASA-PS I-II patients. However, a combination of propofol and esmolol showed a tendency to decrease both the heart rate and arterial pressure and a caution is necessary when the combination were used in elderly patients.

Among the various drugs used, lidocaine has received the most attention. While several studies have demonstrated its ability to decrease the cough reflex, HR and BP increases, ${ }^{23}$ and ICP increases occurring with laryngoscopy, endotracheal intubation, and suctioning, other studies have suggested the lack of efficacy of lidocaine. ${ }^{24}$ It has been used as a lidocaine gargle for oropharyngeal anesthesia, as a lidocaine aerosol for intratracheal anesthesia, ${ }^{25}$ or as an intravenous bolus for systemic anesthesia. ${ }^{26}$ Intravenous lidocaine, in particular, has been found to suppress the cough reflex, ${ }^{27}$ to prevent increases in intracranial pressure, ${ }^{28}$ to attenuate circulatory responses and to possess antiarrhythmic properties. ${ }^{29}$

In our study, there is a better control of HR, SBP, DBP, and MAP with esmolol than lignocaine. The heart rate comes to around baseline after 5 minutes of tracheal intubation. In the case of SBP, DBP and MAP, there is a significant difference in the attenuation of cardiovascular responses by both the drugs $(\mathrm{p}<0.0001)$, a better control provided by esmolol than lignocaine. This study is comparable to the study conducted by $M$ Begum, $P$ Akter demonstrated highly significant reduction in HR, DBP, RPP and MAP in both groups ( $p<0.01), 2$ and 4 minutes after induction. But the SBP reduction was only statistically significant $(\mathrm{p}<0.05)$. In group-E patients, these reductions were more than that of in group-L patients. Four minutes after intubation, HR, SBP, DBP, RPP and MAP returned to almost baseline values in esmolol group. Singh $\mathrm{H}$, Vichitvejpaisal $\mathrm{P}$, et $\mathrm{al}^{30}$ compared the effects of the lidocaine, esmolol, and nitroglycerin and showed lidocaine $1.5 \mathrm{mg} / \mathrm{kg}$ i.v. and nitroglycerin 2 micrograms/kg i.v. were ineffective in 
controlling the acute hemodynamic response following laryngoscopy and intubation. Esmolol $1.4 \mathrm{mg} / \mathrm{kg}$ i.v. was significantly more effective than either lidocaine or nitroglycerin in controlling the HR response to laryngoscopy and intubation $(\mathrm{p}<0.05)$. Following laryngoscopy and intubation, MAP increased in all the group, lignocaine $(55 \%$ $+/-26 \%$ ) heart rate was significantly lower (and esmolol $(25 \%+/-11 \%)$ compared with preinduction baseline values. In esmolol pretreated patients, the increase in heart rate was significantly lower $(20 \%+/-3 \%)$ compared with lignocaine $(52 \%+/-8 \%)$.

Feng C K, Chan K H in their study ${ }^{[28]}$ showed that only esmolol could reliably offer protection against the increase in both HR and SBP and $2 \mathrm{mg} / \mathrm{kg}$ lidocaine had no effect to blunt adverse hemodynamic response during laryngoscopy and tracheal intubation which is in agreement with our study. It is also comparative with another study conducted by Ajay Gupta, Renu Wakhloo, showing a better control of HR, DBP and SBP obtained with esmolol compared to lignocaine. Christopher H. Kindler, Schneider ${ }^{31}$ studied the effects of intravenous lidocaine and/or esmolol on hemodynamic responses to laryngoscopy and intubation and found that esmolol 1 to $2 \mathrm{mg} / \mathrm{kg}$ is reliably effective in attenuating HR in tracheal intubation.

\section{Limitations}

- Varying degree of resting sympathetic tone of patients can cause interference with the readings.

- $\quad$ ASA grade III and IV patients especially with IHD, MI, HTN were not included in study.

- $\quad$ As our sample size is only of 140 patients, so this study cannot be generalized to all ASA I and II patients and further studies with larger sample size is needed.

- Infusion of study drugs after bolus might have yielded better results than single bolus dose of study drugs. Which require more studies in future.

- Influence of premedication with glycopyrrolate, which cause tachycardia might have interfered with the readings.

\section{CONCLUSIONS}

Thus, from our study we conclude that in patients with ASAPS grade I and II, intravenous bolus dose of Lignocaine $(1.5 \mathrm{mg} / \mathrm{kg})$ and Esmolol $(1.5 \mathrm{mg} / \mathrm{kg})$ given 3 minute prior to laryngoscopy and intubation is safe and effective prophylactic method for attenuating hemodynamic response to laryngoscopy and intubation. Esmolol provides reliable and consistent protection against rise in pulse rate and blood pressure. Esmolol provides better cardio-protection in patients against hyperadrenergic responses to laryngoscopy and endotracheal intubation. Esmolol appears to be the drug of choice in maintaining hemodynamic stability during laryngoscopy and intubation.

Data sharing statement provided by the authors is available with the full text of this article at jemds.com.

Financial or other competing interests: None.

Disclosure forms provided by the authors are available with the full text of this article at jemds.com.

\section{REFERENCES}

[1] Wilson IG, Meiklejohn BH, Smith G. Intravenous lignocaine and sympathoadrenal responses to laryngoscopy and intubation: the effect of varying time of injection. Anaesthesia 1991;46(3):177-80.

[2] King BD, Harris LC, Greifenstein FE, et al. Reflex circulatory responses to direct laryngoscopy and tracheal intubation performed during general anesthesia. Anesthesiology 1951;12(5):556-66.

[3] Gupta C, Rastogi B, Agarwal S, et al. Clinical efficacy of esmolol, lignocaine and diltiazem as premedicant for attenuation of hemodynamic responses of laryngoscopy and endotracheal intubation - a comparative evaluation. Int J Res Med Sci 2017;5(10):4443-9.

[4] Gupta A, Wakhloo R, Gupta V, et al. Comparison of esmolol and lignocaine for attenuation of cardiovascular stress response to laryngoscopy and endotracheal intubation. JK Sci 2009;11(2):78-81.

[5] Singh S, Laing EF, Singh A. Comparison of esmolol and lidocaine for attenuation of cardiovascular stress response to laryngoscopy and endotracheal intubation in a Ghanaian population. Anesth Essays Res 2013;7(1):838.

[6] Kovac AL. Controlling the hemodynamic response to laryngoscopy and endotracheal intubation. J Clin Anesth 1996;8(1):63-79.

[7] Bruder N, Ortega D, Granthil C. Consequences and prevention methods of hemodynamic changes during laryngoscopy and intratracheal intubation. In: Annales francaisesd'anesthesieet de reanimation 1992:57-71.

[8] Savio KH, Tait G, Karkouti K, et al. The safety of perioperative esmolol: a systematic review and metaanalysis of randomized controlled trials. Anesth Analg 2011;112(2):267-81.

[9] Adi MNAM, Keszler H, Yacoub JM. Cardiovascular reactions to laryngoscopy and tracheal intubation following small and large intravenous doses of lidocaine. Can Anaesth Soc J 1977;24(1):12.

[10] Miller CD, Warren SJ. IV lignocaine fails to attenuate the cardiovascular response to laryngoscopy and tracheal intubation. Br J Anaesth 1990;65(2):216-9.

[11] Shribman AJ, Smith G, Achola KJ. Cardiovascular and catecholamine responses to laryngoscopy with and without tracheal intubation. $\mathrm{Br} J$ Anaesth 1987;59(3):295-9.

[12] Russell WJ, Drew S, Morris R, et al. Changes in plasma catecholamine concentrations during endotracheal intubation. Br J Anaesth 1981;53(8):837-9.

[13] Derbyshire DR, Chmielewski A, Fell D, et al. Plasma catecholamine responses to tracheal intubation. $\mathrm{Br} \mathrm{J}$ Anaesth 1983;55(9):855-60.

[14] Thomson IR. The haemodynamic response to intubation: a perspective. Can J Anesth Can Anesth 1989;36(4):3679.

[15] Burney RG, Winn R. Increased cerbrospinal fluid pressure during laryngoscopy and intubation for induction of anesthesia. Anesth Analg 1975;54(5):68790.

[16] Yukioka H, Yoshimoto N, Nishimura K, et al. Intravenous lidocaine as a suppressant of coughing during tracheal intubation. Anesth Analg 1985;64(12):1189-92. 
[17] White PF, Schlobohm RM, Pitts LH, et al. A randomized study of drugs for preventing increases in intracranial pressure during endotracheal suctioning. Anesthesiology 1982;57(3):242-4.

[18] Hamill JF, Bedford RF, Weaver DC, et al. Lidocaine before endotracheal intubation: intravenous or laryngotracheal? Surv Anesthesiol 1982;26(5):270.

[19] Vucevic M, Purdy GM, Ellis FR. Esmolol hydrochloride for management of the cardiovascular stress responses to laryngoscopy and tracheal intubation. $\mathrm{Br} \mathrm{J}$ Anaesth 1992;68(5):529-30.

[20] Louizos AA, Hadzilia SJ, Davilis DI, et al. Administration of esmolol in microlaryngeal surgery for blunting the hemodynamic response during laryngoscopy and tracheal intubation in cigarette smokers. Ann Otol Rhinol Laryngol 2007;116(2):107-11.

[21] Ebert JP, Pearson JD, Gelman S, et al. Circulatory responses to laryngoscopy: the comparative effects of placebo, fentanyl and esmolol. Can J Anaesth 1989;36(3):301-6.

[22] Korpinen R, Simola M, Saarnivaara L. Effect of esmolol on the hemodynamic and electrocardiographic changes during laryngomicroscopy under propofolalfentanil anesthesia. Acta Anaesthesiol Belg 1998;49(2):123-32.

[23] Lev R, Rosen P. Prophylactic lidocaine use preintubation: a review. J Emerg Med 1994;12(4):499-506.

[24] Pathak D, Slater RM, Ping SSS, et al. Effects of alfentanil and lidocaine on the hemodynamic responses to laryngoscopy and tracheal intubation. J Clin Anesth 1990;2(2):81-5.

[25] Denlincer JK, Ellison N, Ominsky AJ. Effects of intratracheal lidocaine on circulatory responses to tracheal intubation. Anesthesiology 1974;41(4):409-12.

[26] Donegan MF, Bedford RF, Hunter AR. Intravenously administered lidocaine prevents intracranial hypertension during endotracheal suctioning. Surv Anesthesiol 1981;25(3):154.

[27] Poulton TJ, James FM. Cough suppression by lidocaine. Anesthesiol J Am Soc Anesthesiol 1979;50(5):470-2.

[28] McGillicuddy JE. Cerebral protection: pathophysiology and treatment of increased intracranial pressure. Chest 1985;87(1):85-93.

[29] Collinsworth KA, Kalman SM, Harrison DC. The clinical pharmacology of lidocaine as an antiarrhythymic drug. Circulation 1974;50(6):1217-30.

[30] Singh H, Vichitvejpaisal P, Gaines GY, et al. Comparative effects of lidocaine, esmolol, and nitroglycerin in modifying the hemodynamic response to laryngoscopy and intubation. J Clin Anesth 1995;7(1):5-8.

[31] Kindler CH, Schumacher PG, Schneider MC, et al. Effects of intravenous lidocaine and/or esmolol on hemodynamic responses to laryngoscopy and intubation: a double-blind, controlled clinical trial. J Clin Anesth 1996;8(6):491-6. 